\title{
Nietzsche e Villa-Lobos: da música dionisíaca à canção folclórica
}

Nietzsche and Villa-Lobos: from Dionysian music to folk song

\section{Márcio José Silveira Lima Universidade Federal do Sul da Bahia}

\section{RESUMO}

O artigo expõe aspectos da concepção de Nietzsche sobre a música dionisíaca, tentando apontar para possíveis convergências com a estética do compositor Villa-Lobos, cujas composiçôes foram marcadas pela utilização de temáticas e escalas folclóricas. Trata-se de compreender a música dionisíaca em sua relação com a mitologia, defendendo que a noção de cultura trágica que decorre dessa relação significa para Nietzsche uma possibilidade de superação dos valores cristalizados há séculos no Ocidente, tanto em termos morais, quanto musicais. De igual maneira, ao enfatizar a importância da canção folclórica para a linguagem musical, Villa-Lobos se insere num contexto de superação da linguagem musical dominada pela escala tonal, ao mesmo tempo em que utiliza de seus procedimentos estéticos para uma intensa inserção no debate cultural de sua época em torno da identidade nacional brasileira.

\section{PALAVRAS-CHAVE}

Nietzsche; Villa-Lobos; Música;

Canção Dionisíaca;

Música Folclórica.

\begin{abstract}
The paper exposes aspects of Nietzsche's conception of Dionysian music, trying to find possible points of convergence with the aesthetics of the composer Villa-Lobos, whose compositions are known for the use of folk themes and scales. The paper should try to understanding Dionysian music in its relation to mythology, and it argues that the notion of tragic culture that derives from this relationship means for Nietzsche a possibility of overcoming the values crystallized centuries ago in the West, both in moral and musical terms. In emphasizing the importance of the folk song for the musical language, Villa-Lobos relates to a movement that tries of overcoming the musical language dominated by the tonal scale, at the same time that making use of its aesthetic procedures for an intense insertion in the cultural debate of his time around Brazilian national identity.
\end{abstract}

\section{KEY WORDS}

Nietzsche; Villa-Lobos; Music;

Dionysian Song;

Folk Music. 


\section{Música, cultura e novos valores em Nietzsche}

Embora o problema dos valores comece a aparecer de forma bem delineada na obra de Nietzsche a partir das obras tardias, é possível considerar que a questão axiológica já está presente em suas reflexóes iniciais. Tanto a interpretação sobre a cultura trágica na Grécia arcaica, quanto os motivos que levaram a seu ocaso, estão permeados de preocupaçôes que revelam um modo de valorar em estreita ligação com os dois movimentos. Ainda mais, a esperança de que uma nova cultura trágica pudesse surgir no mundo moderno mediante a superação do socratismo tinha como pano de fundo um movimento dialético ${ }^{\mathrm{I}}$ de renascimento da força dionisíaca. Na importante interpretação que fará de $O$ Nascimento da Tragédia, Nietzsche, no "Ensaio de autocrítica" que lhe acrescenta à guisa de posfácio, elege alguns problemas que destacam a importância da música para a cultura trágica, e de como suas teses se convertem em relevantes reflexôes sobre os valores. A primeira questão diz respeito à necessidade dos gregos para a arte. Sob o ponto de vista do pessimismo, como entender a relação entre música e tragédia, entre gregos, música e tragédia? Por que, segundo Nietzsche, o povo que mais seduziu para o viver teria necessidade de uma arte trágica? É certo que essas questões, não obstante estarem presentes no livro, são reformuladas a partir de um longo processo de maturação, e apenas se entendermos o acerto de contas com o romantismo poderemos bem compreender essa outra dimensão da obra.

Um texto importante para essa compreensão é o parágrafo 370 de $A$ gaia Ciência, no qual Nietzsche faz uma diferenciação entre dois tipos de romantismo, que acaba por estabelecer duas formas de pessimismo. Um que, ante a percepção dura e cruel da realidade, cria valores que afirmam a vida ao superar essa percepção; outro, que, diante da visão terrível da existência, sucumbe no niilismo e na condenação da realidade. Um busca por mar calmo e quietude; o outro anseia pelo turbilhão caótico de forças naturais. ${ }^{2} \mathrm{O}$ que há de insólito nessa tese de Nietzsche, quando se tenta lançar luz sobre a consideração trágica do mundo na Grécia arcaica, é que ela parece imprimir uma espécie de subversão valorativa. Com efeito, os gregos teriam sido pessimistas justamente no período de sua juventude, quando o povo demonstra o vigor de uma cultura nascente. A cultura trágica grega do período arcaico, por paradoxo, seria a prova de que os gregos foram pessimistas e felizes nos seus albores; ao contrário, como Nietzsche interpreta o fenômeno do socratismo, os gregos teriam sido otimistas justamente em seu período senil, quando entraram em decadência.

I Assim Nietzsche interpretará mais tarde na autocrítica e na apresentação que fará de O Nascimento da Tragédia em Ecce Homo (O Nascimento da Tragédia, "Ensaio de autocrítica", $\$ 2, KSA I.I4; Ecce Homo, "O Nascimento da Tragédia", \ I, KSA 6.309).

2 Cf. A gaia Ciência $\$ 370$, KSA 3.619. 
É essa a interpretação dada por Nietzsche para as duas respostas gregas diante do problema comum acerca do significado da existência. $\mathrm{O}$ otimismo socrático estava fundado na crença de que esse problema poderia encontrar sua resposta num otimismo baseado no poder da razão, que poderia penetrar na essência última das coisas e com isso corrigir a própria vida. Essa teria sido a meta a que se propôs Sócrates ao combater poetas, oradores, estadistas e artistas, condenando a arte e a ética vigentes porque davam testemunho de uma falta de compreensão do próprio fazer de cada um dos gregos, uma vez que agiam por instinto. "A partir desse único ponto julgou Sócrates que devia corrigir a existência: ele, só ele, entra com ar de menosprezo e de superioridade, como precursor de uma cultura, arte e moral totalmente distintas".

Nietzsche extrai duas teses que se complementam ao sentenciar a influência decisiva de Sócrates para a cultura grega. A primeira, é que ele teria inaugurado um tipo de avaliação que se tornaria comum sobre os gregos, ou seja, uma explosão de fúria sempre renovada por parte de outras culturas que julgavam aquele pequenino povo [Völkchen] arrogante, julgando bárbaro todo estrangeiro ${ }^{4}$. Assim, aquele ressentimento contra os gregos, que se tornaria comum ao longo dos tempos, teve em Sócrates seu primeiro exemplo. Além disso, e em segundo lugar, ao condenar a cultura grega vigente, Sócrates teria erigido uma outra visão de mundo, que, aos olhos de Nietzsche, teria decidido o destino da cultura ocidental. A despeito disso, é também sintomático que a acusação renovada, de que foram vítimas os gregos, jamais conseguiria dar cabo daquela cultura helênica. Nesse sentido, diz Nietzsche, as acusações nunca vieram acompanhadas da cicuta. E esse é um elemento crucial para o filósofo, porque na estratégia, adotada no contexto de $O$ Nascimento da Tragédia, de luta em torno dos valores, esse vigor grego cumpre um papel decisivo. Em outras palavras: o ressentimento contra a cultura grega nunca fez com que ela sofresse os efeitos letais a ponto de desaparecer; antes, teria permanecido influente, sendo essa vitalidade um traço a ser amiúde destacado por Nietzsche.

Mais uma vez, entra em cena aquele jogo dialético, agora transposto para o plano histórico. Com efeito, Nietzsche julga que, no mundo grego, a arte trágico-dionisíaca foi suplantada pelo combate que, em última instância, moveu o socratismo contra a tragédia esquiliana. No entanto, esse mesmo socratismo teria seu fundamento último, ou seja, o otimismo metafísico, suplantado pelas concepções filosóficas alemãs, primeiro a de Kant, depois a de Schopenhauer. Enquanto Kant pôs fim ao otimismo que julgava conhecer a essência última de

O Nascimento da Tragédia $\$$ I3, KSA I.89.

4 Cf. O Nascimento da Tragédia $\$$ I5, KSA I.97. 
uma realidade em si, Schopenhauer, na mesma senda, trouxe de volta uma concepção pessimista, e, sobretudo, alçou a música ao pináculo da esfera artística. A possibilidade de uma vitória de uma nova cultura trágica sobre a consideração otimista de mundo, e, em harmonia com isso, o surgimento outra vez de uma nova concepção artística que fosse superior à visão científica poderiam levar a uma "transmutação" [Umschlagen]' do presente. ${ }^{6}$

Nietzsche afirma que o sortilégio dessas lutas é que quem as olha também tem de lutá-las. Essa parece ser uma forma de apontar para uma das metas de O Nascimento da Tragédia, ou seja, uma tomada de partido nessa luta, nessa interação ao mesmo tempo conflituosa e harmônica entre a obra de arte trágico-musical, de um lado, e filosofia, de outro. Se a filosofia socrática, por meio de uma transmutação radical, foi a responsável pelo fim da obra de arte trágica, na Alemanha a mudança de rotação provocaria uma inversão de sentido, na medida em que a filosofia, primeiro com Kant e Schopenhauer, e depois com o próprio Nietzsche, abriria o caminho para uma nova transmutação, fazendo retornar a obra de arte trágica, agora realizada por Richard Wagner. Se filosofia e arte, com Sócrates, estiveram em oposição mortal na Grécia, na Alemanha elas caminhavam juntas.

\section{0 retorno da música dionisíaca}

No parágrafo 16 de $O$ Nascimento da Tragédia, Nietzsche começa a apresentar a arte musical de Wagner como possibilidade de ressurgimento de uma cultura trágica, tal como havia ocorrido entre os gregos; para isso, ele retoma teses centrais do livro que até então já haviam sido expostas, sobretudo a discussão entre música e palavra e sua relação com os princípios estético-metafísicos do dionisíaco e do apolíneo. Por fim, faz uma longa citação de O Mundo como Vontade e Representação, para corroborar seus argumentos. Schopenhauer afirma que a música, diferente das demais artes, presas ao mundo da representação, é uma objetidade [Objetktität] imediata da vontade. Por isso, considera que o mundo é tanto música quanto vontade corporificada. Nisso a música se assemelha às figu-

5 Os tradutores para o português, espanhol, francês e inglês têm alternado a tradução do termo Umschlagen por transformação, transmutação ou mudança. Não é raro encontrarmos em português o termo transmutação para traduzir Umwertung, cuja versão mais corrente entre nós é transvaloração. Também Sanchez Pascual, tradutor para o espanhol, verte Umschlagen para transmutação, e mantém transvaloração para traduzir Umwertung. Seguimos aqui, portanto, essa que parece ser a intenção do tradutor espanhol, que pode ter pretendido indicar a semelhança de ideias vinculadas por Nietzsche em momentos distintos de sua obra. Com efeito, toda a discussão em torno do efeito da filosofia socrática para a cultura grega, bem como a necessidade de superá-la, antecipa de forma seminal a meta final da filosofia nietzschiana sintetizada na expressão transvaloração de todos os valores.

6 Cf. O Nascimento da Tragédia \$ I5, KSA I.97. 
ras geométricas em sua universalidade abstrata, e sua corporificação no mundo revela por que as melodias, em combinações infinitas, tornam possíveis todos os objetos da experiência, incluindo os sentimentos dos processos interiores dos seres humanos. Afim a esse espírito schopenhauriano, Nietzsche oferece uma nova formulação. Como arte dionisíaca e não figurada, a música seria essa linguagem universal de que fala Schopenhauer, e, mediante seu poder de corporificação no mundo da experiência, seria a responsável por fazer jorrar as imagens e as palavras que estão no fundo de toda cultura mitológica. Portanto, se Dioniso e Apolo são duas divindades a que se filiam, respectivamente, as artes não figuradas da música e as figuradas da poesia épica e da pintura, o universo mítico, embora na sua aparência seja conceitual, imagética e por isso figurativa, esconde seu fundo musical e sem forma determinada. Desse modo, o processo que leva à máxima potência expressiva da música vai da poesia épica e lírica à tragédia grega, quando a relação entre mito, palavra e música são conduzidos por esta última na arte dramática.

A história da gênese da tragédia grega nos diz agora, com luminosa nitidez, que a obra de arte trágica dos gregos nasceu realmente do espírito da música: mediante esse pensamento cremos ter feito justiça pela primeira vez ao sentido originário e tão assombroso do coro. Mas ao mesmo tempo temos de admitir que o significado antes exposto do mito trágico nunca chegou a ser transparente com a claridade conceitual, aos poetas gregos, e menos ainda aos filósofos gregos. [...] No que se refere à tragédia grega, que se nos apresenta, certamente, só como drama falado, sugeri inclusive que essa incongruência entre mito e palavra poderia nos induzir com facilidade a tomá-la por mais superficial do que aquela que, segundo o testemunho dos antigos, teve de produzir: porque facilmente se esquece de que aquilo que o poeta das palavras não havia conseguido, isto é, alcançar a idealidade e espiritualização do mito, podia consegui-lo a todo instante como músico criador. $^{7}$

Se a música é a principal responsável pela erupção dos principais elementos da cultura, ela não teria ficado imune à influência da filosofia de Sócrates, na medida em que teria também enredado por esse caminho de negação de sua essência dionisíaca. Após a atuação socrática, a música dionisíaca perderia a força sonora expressa no coro com sua filiação ditirâmbica; a partir de então, percorreria o caminho aberto pelo novo ditirambo ático, uma reprodução da aparência mediada por conceitos. Daquela perspectiva axiológica, duas tendências conflituosas haviam se estabelecido na antiguidade grega: a consideração teórica e a consideração trágica do mundo [der theoretischen und der tragischen Weltbetrachtung]. Diante desse embate entre as duas considerações do mundo, com a visão teórica 
sobrepujando a trágica, a música deixou de ser a fonte de formação dos mitos, portanto, da cultura, para ser apenas um "estimulante para nervos embotados" ou uma "pintura sonora".

Nesse sentido, Nietzsche defende a singularidade da música de Wagner, pois com Tristão e Isolda o compositor daria um passo para além desses limites impostos à música, liberando-a para expressar sua essência mais própria, quer dizer, a própria essência do mundo, tal como expunha Schopenhauer, retomando, assim, aquela potência sonora dionisíaca da tragédia grega, tal como antes expusera o próprio Nietzsche. E a tendência socrático-teórica musical a que a obra wagneriana iria se contrapor seria a ópera, que, grosso modo, pode ser entendida como uma construção teórica pelo menos por dois motivos: pelo processo mesmo de concepção e pelos procedimentos artísticos adotados. No primeiro caso, prova-o o fato de pensadores italianos terem concebido um tipo de obra de arte que, unindo música, palavra e drama, faria reviver a tragédia grega. ${ }^{9}$ Mas esse programa estético é ele próprio estranho à natureza da arte, pois atendia à exigência de críticos que, no caso musical, exigiam que a palavra, para ser compreendida, acabava por subjugar a música. Já na sua concepção, a ópera traz aquele gesto fundador em que a palavra domina o contraponto como o senhor domina o servo. No segundo caso, a forma dessa união, aos olhos de Nietzsche, negava tanto o que há de apolíneo, quanto o de dionisíaco na arte trágica antiga. No fim, a ópera, com seu mosaico artístico, atua ora sobre o conceito, ora sobre a representação, ora sobre o fundo musical do ouvinte, sem nunca alcançar, contudo, uma consistência interna. Eis por que a ópera seria antiartística. ${ }^{\text {IO }}$

$\mathrm{Na}$ contramão do fenômeno artístico que a ópera representava, Nietzsche afirma que a música alemã tem um curso solar que vai de Bach a Beethoven e deste a Wagner. Ora, além dos elementos artísticos musicais, a obra de Wagner situava-se numa constelação que propiciou essa contraposição à tendência teórica na música, abrindo-se, com isso, à possibilidade do retorno do espírito trágicodionisíaco. Para que a música de Wagner movesse outra vez as forças dionisíacas, foi necessário antes a supressão do otimismo socrático na filosofia, assim como a resistência da música de Bach e Beethoven à tendência operística. Além disso, Nietzsche não desconsidera a importância de Lutero, uma vez que ele teria sido

8 O Nascimento da Tragédia $\$$ I7, KSA I.IO9.

9 A esse respeito, a crítica de Nietzsche se concentra no parágrafo I9 de O Nascimento da Tragédia. Para uma discussão histórica sobre o surgimento da ópera e sua relação com a tragédia, ver Carolyn Abbate \& Roger Parker (20I2). Os autores mostram como essa visão - de que Nietzsche é tributário - se impôs até o século XIX, mas que, ao longo do século xx (p. I4Iss.) começou a haver muitas outras visōes sobre o surgimento da ópera, sobretudo os muitos experimentos que reuniam canto, dança e música.

Io Cf. O Nascimento da Tragédia $\$$ I9, KSA I.I2I. 
o responsável por impor à cultura alemã não só o cultivo da música como uma de suas mais singulares expressões, como também teria dado a condição para a coesão cultural com sua tradução da bíblia e o consequente cultivo da língua como catalisador.

Nietzsche afirma ainda que os procedimentos musicais adotados por Wagner, em Tristão e Isolda, tinham força bastante para libertar a música da linguagem que teve de adotar desde o fim da tragédia por intermédio da influência socrática. $\mathrm{O}$ que essa obra wagneriana consegue restituir é aquela relação, só antes atingida pela tragédia grega, de fatos universais expressos por meio da união entre a música e o mito trágico, na figura do herói. Nietzsche apresenta várias passagens do terceiro ato de Tristão, delas destacando toda a força existente na interação entre música, palavra, mito, imagens e conceitos, bem como o vínculo profundo entre esses elementos e o jogo entre o dionisíaco e o apolíneo. Após o lamento do herói, em que a trompa conduz para a desmesura que revela a compreensão profunda do caráter vão da existência, tem-se uma redenção apolínea na atuação do personagem Kurwenal. Nietzsche afirma o caráter dionisíaco da obra wagneriana, inclusive em sua relação com o apolíneo, tal como ocorria na tragédia grega; além do mais, conclui que essa relação entre os dois princípios míticos e musicais

faz desfilar diante de nós imagens da vida e nos incita a captar com o pensamento o núcleo vital nelas contido. Com a energia enorme da imagem, do conceito, da doutrina ética, da excitação simpática, o apolíneo arrasta o homem para fora de sua autoaniquilação orgiástica e, passando enganosamente por sobre a universalidade do sucesso dionisíaco, o leva à ilusão de que ele vê só uma imagem do mundo, por exemplo Tristão e Isolda, e que, mediante a música, tão só há de vê-la melhor e mais intimamente. ${ }^{\mathrm{I}}$

\section{Villa-Lobos e a importância da música folclórica para a cultura nacional}

A reflexão sobre a importância da música no contexto das identidades culturais nacionais é, por óbvio, anterior ao projeto wagneriano de reforma da música em vista da tradição alemã, bem como às teses de Nietzsche em $O$ Nascimento da Tragédia. Todavia, como o filósofo sugere, na esteira da consideraçôes teóricomusicais de Wagner, há algo de singular na música de seu contemporâneo frente à estética perseguida pela geração romântica que lhes antecede. O passo além dado por Wagner está amparado na apropriação mesma que ele faz do legado da música alemã, uma vez que, do ponto de vista sonoro, reformula a relação entre

II O Nascimento da Tragédia $\$ 2$ I, KSA I.I37. 
música e palavra, na medida em que seu drama toma como princípio musical a expressividade sinfônica, e, da perspectiva literária, trabalha com a tradição mítico-popular dos povos germânicos.

Quando Nietzsche elogia a música de Wagner porque ela estaria dando vida outra vez ao espírito dionisíaco, ele está, no fundo, mirando as formulações musicais do compositor, com cujas inovaçôes teria saído para fora do caminho estreito pelo qual enveredou a música moderna, em especial a ópera. Os acordes com que Wagner abriu seu caminho harmônico teriam, pois, feito renascer o espírito desmedido (dissonante) da música dionisíaca. E esse duplo caminho aberto por ele, o da busca por uma nova sonoridade e do seu vínculo estreito com a cultura mitológica popular, de um modo ou de outro, significaram uma conquista importante para grande parte da estética musical que se lhe seguiu.

Nesse sentido, uma tendência bastante significativa da música no século xx não apenas procurou uma nova linguagem com que se expressar, frente o "crepúsculo" do sistema tonal, como foi buscar nos folclores nacionais uma forma dessa expressão. O húngaro Bela Bartók e o checo Leos Janácek ${ }^{\mathrm{I}}$, para mencionar dois nomes importantes da música europeia, seguiram esse caminho. No Brasil, o mesmo acontece com Villa-Lobos, cuja obra musical é marcada pela estética modernista, inclusive por sua participação na semana de 22, e, seguindo a tendência daqueles dois compositores europeus, buscou por novas sonoridades, tendo a música popular e folclórica desempenhado um papel fundamental. Como afirma Jankélévicht, Bartók não se prende a nenhum preconceito, a nenhuma conveniência tradicional. "Tanta audácia e desenvoltura aparentam Bartók a um gênio da mesma têmpera, ao rapsodo da floresta virgem Villa-Lobos, o autor do Rude poema, que também é um prático do murro e da percussão furiosa". ${ }^{13}$

Já desde o início de sua trajetória musical, Villa-Lobos traz essa dupla característica de sua obra, um posicionamento que buscava uma apropriação das estruturas harmônicas modernas e não apenas tonais e a utilização de material popular e folclórico. Em menor medida, Wagner será uma influência para algumas de suas composiçõos, e, com maior intensidade, Debussy e Stravinsky deixarão marcas significativas em sua obra, sobretudo o compositor francês. ${ }^{\mathrm{I}}{ }^{4}$ Se essa du-

I2 Sobre a relação entre música popular e folclórica, e a diferenciação dos compositores modernos em relação aos românticos no que tange a essa questão, ver nosso artigo: Lima, 20I7, p. 75ss.

I3 Jankélévicht, I994, p. 319.

I4 A propósito das influências que marcaram a trajetória de Villa-Lobos, ver Bruno Kiefer (I986, pp. II-65); especialmente sobre Stravinsky e Debussy, ver Guilherme Bernstein (20I4, pp. 73-8I); sobre Wagner, Paulo de Tarso Salles (20II, pp. I9-40), afirma, com relação ao diálogo e da posição estética que com ele trava o compositor brasileiro: "Vemos a influência de Wagner estender-se pelas gerações seguintes, manifestando-se em 
pla tendência representou um apelo forte na obra de Villa-Lobos, da perspectiva dos valores, do ethos, o compositor partiu do princípio de que a música, em sua época, havia chegado a um nível questionável, dada o seu caráter experimental. $\mathrm{Na}$ sua visão, a música deveria ser criadoramente robusta. Assim, se as novas formulações musicais lhe forneceram recursos importantes para suas composições, era importante que esses novos caminhos não estivessem a serviço apenas de experimentação. Por isso, a música popular e folclórica lhe serão decisivas. ${ }^{15}$

Villa-Lobos assim define a música folclórica:

A música folclórica é a expansão, o desenvolvimento livre do próprio povo expresso pelo próprio som. Mesmo se tal música não é popular, continua a ser folclórica. Música folclórica é sua expressão biológica. A arte da música, que pode ser folclórica e popular, ou nem uma coisa ou nem outra, representa a mais alta expressão criadora de um povo. A grande música, a mais alta, é a que, originando-se numa dessas três fontes, alcança, no entanto, uma expressão humana universal. ${ }^{16}$

O primeiro aspecto que chama a atenção, nessa passagem, é distinção entre as três fontes em que bebe a música: ou no folclore, ou na arte popular ou em outra ainda, que não é nomeada pelo compositor. A própria obra de Villa-Lobos pode nos indicar que esse terceiro componente pode ser, por exemplo, a estrutura musical das obras de Bach, da qual ele se apropriou no ciclo de composições denominado Bachianas brasileiras (do qual falaremos adiante). Por outro lado, ao fazer a distinção entre a música popular e folclórica, Villa-Lobos parece afastar-se de uma certa identificação inicial entre as duas esferas, sem, contudo, adotar ainda uma visão que hoje já é bastante disseminada sobre o que seja a música popular.

arquétipos harmônicos derivados do acorde de Tristão (acordes construídos por Quartas superpostas) e mesmo em citações temáticas recorrentes. Longe de mostrarem um caráter passadista, nostálgico, as obras de Villa-Lobos demonstram o mesmo tipo de inquietude da geração que estabeleceu o modernismo na Europa" (pp. 34-35).

I5 Um bom cenário em torno das discussões estéticas e do lugar que nelas Villa-Lobos ocupou no Brasil nos é dada por Willy Corrêa de Oliveira (2009). O autor expõe sua própria trajetória, explicando por que, no início, preferiu seguir os caminhos da vanguarda musical em detrimento do nacionalismo musical e folclórico seguido por Villa-Lobos. A seu ver, a utilização do material folclórico servia apenas para mal substituir as soluções dialéticas que já haviam sido abolidas por Liszt e Debussy (p. 28). Apesar disso, Willy Corrêa revê seu posicionamento diante das peças para piano as cirandas. Fiel a programa estético de Villa-Lobos, essas peças para piano testemunham mais uma vez o uso que ele fez do folclore como fonte de suas composições. Sobre elas, enfim, Willy Corrêa afirma: "E me foi possível receber o significado delas como quem se abre para uma epifania. As teorias da música preconizam modos muito testados, mais antigos, de escrever música, e Villa-Lobos não experimentou necessidades de aproximaçôes desses conhecimentos para a feitura de sua música nova. Não é necessário, creio, escrever aqui que Villa-Lobos é um milagre" (p. 49).

I6 Villa-Lobos, I97I, p. 96. 
No Brasil, quando nos referimos, por exemplo, à MPB, por mais ampla que possa ser a sigla em termos das expressóes culturais que abrange, não confundimos com o que possa ser uma peça denominada de música erudita, clássica, ou ainda de uma canção folclórica. Assim, é sem maiores dificuldades que uma canção de Tom Jobim será chamada de música popular, uma peça de Beethoven de erudita ou clássica, e que Boi da cara preta será reconhecida como uma canção folclórica.

Como dissemos, ao fazer uma delimitação entre o que é popular e o que é folclórico, na música, Villa-Lobos ainda não partilha de nossos "critérios" atuais. A própria palavra, de origem inglesa, já traz a marca original dessa identificação, uma vez que folk-lore significa aquilo que revela as antiguidades populares. ${ }^{17} \mathrm{Nesse}$ sentido, popular designa, por assim, dizer, a essência do folclore. Nietzsche, por exemplo, quando se refere à cultura mítica da Grécia antiga, de sua tradição ditirâmbica, e de como a música aí encontrou um meio de expressão, denomina uma das formas de ser da arte sonora grega de Volkslied $^{18}$, que poderíamos traduzir por canção popular, mas no sentido do que então era considerada a canção folclórica. Há nesse caso, portanto, uma identificação entre o popular e o folclórico.

No caso de Villa-Lobos, ele simplifica a questão, considerando que música popular é aquela que o público tanto aprecia. ${ }^{\text {19 }}$ Ou seja, se uma música, independente de qual possa ser seu formato, é apreciada pelo público, ela é popular. Popular, portanto, é aquilo de que o povo gosta. É preciso compreender essa distinção à luz do projeto e das ambições culturais que foram tão importantes para o compositor, e das quais sua obra dá um testemunho de compromisso cultural e estético. Ora, se há uma certa condenação da música popular, visto sob essa ótica, não se trata, também, de confundir o gosto do público como uma espécie de adesão à crítica à indústria cultural ou de massa. ${ }^{20}$ Em linhas gerais, quando lamenta que os "jovens são animados a ouvir o que apreciam e o fazem como lhes apraz" ${ }^{31}$, o compositor escande sua crítica a esse apelo popular da música tendo em vista aquilo que define a música folclórica, ou seja, o quanto ela é a expressão do som para a alma do povo. Por isso mesmo, uma música que agrada a um público

I7 Para uma discussão sobre o surgimento do termo folclore e de seu desenvolvimento, ver Renato Almeida (1974).

I8 Cf. O Nascimento da Tragédia $\$ 6$, KSA I.48.

I9 Villa-Lobos, I97I, p. 96.

20 Isso não significa, contudo, que o compositor não tivesse um posicionamento claro acerca dos modernos mecanismos de divulgação cultural e de envolvimento popular, como o rádio, o cinema, o carnaval e o futebol. Na visão do compositor, se esses meios não ultrapassassem, como não raro acontece, os limites do bom senso, poderiam ser importantes na formação artística de um povo (Villa-Lobos, I970, p. IO2).

2I Villa-Lobos, I97I, p. 96. 
e se torna popular pode muito bem ser estranha a esse mesmo público. ${ }^{22}$

Como Villa-Lobos está pensando em termos de uma arte que possa representar a alma de um povo, e, que, além disso, integre um projeto pedagógico que perseguisse uma educação musical, a música folclórica seria o melhor caminho, evitando, assim, os "falsos valores", os quais, eventualmente, a música popular pode veicular. De fato, com esse ímpeto, Villa-Lobos assumiu, na década de I930, o projeto do Canto Orfeônico, que estava voltado para a educação musical em grande escala no Brasil. ${ }^{23}$ Nos termos da visão cultural e artística, o Canto Orfeônico significava uma contrapartida pedagógica de Villa-Lobos para uma boa formação por meio da música. Naquele momento singular de florescimento da cultura brasileira em diversas direçôes, é possível considerar essa atuação pedagógica como a possibilidade de ampliação do imenso trabalho musical já impregnado da profusão de culturas folclóricas. Seria uma maneira de devolver ao povo aquilo que ele mesmo criou, por meio de uma educação ampla. "O verdadeiro ideal do artista é servir a massa do povo, dar-lhe alguma coisa que, graças aos seus sons naturais, só ele pode dar". ${ }^{24}$

Uma vez que a música no Brasil viveu mais ou menos divorciada de sua verdadeira finalidade musical, era preciso ampliar a esfera de atuação musical por meio da utilização do material folclórico, de sorte a devolver ao povo aquilo que ele mesmo criou. O que implica, também, ir em busca de uma formação da consciência musical brasileira. Villa-Lobos vai buscar longe a ideia da importância da música para a formação de um povo, na medida em que afirma que, na Grécia, a música foi um elemento básico e insubstituível na formação espiritual do povo. Contudo, esse trabalho ainda estava por ser feito no Brasil, tendo em vista a dimensão e diversidade de nossa cultura. De forma muito breve, Villa-Lo-

22 Sobre essa discussão acerca da música popular e folclórica, Wisnic lembra que há toda uma corrente de compositores nacionalistas, além de Villa-Lobos, que mantiveram uma ligação com a música popular, tais como Mignone, Lorenzo Fernandez e Camargo Guarnieri. Esses compositores faziam uma distinção entre a música folclórica, de caráter rural, e a popular, produzida nas cidades, para tomar partido sempre pela primeira como genuína expressão brasileira. Todavia, defende Wisnic, em Villa-Lobos essa cisão é mais nuançada, sobretudo porque o compositor desde o início de sua trajetória buscou inspiração entre os chorões. Com isso, buscava unir a música urbana, sendo o choro o modelo privilegiado, com outras formas musicais, como a dos indígenas, primitivas e negras (Wisnic, I982, pp. I3I-I36).

23 A bem da verdade, Anísio Teixeira relata que, à época em que era diretor do Departamento de Educação do Rio Janeiro, então capital do Brasil, convidou, em I932, Villa-Lobos para dirigir o setor de educação musical das escolas. Surge daí a ideia do Canto Orfeônico. Nas palavras de Anísio, durante os quatro anos que esteve à frente do projeto, o compositor fez-se educador do povo. "Não sei de esforço maior para a nossa integração em uma cultura própria e autóctone" (Anísio Teixeira, 1965, p. I4).

24 Villa-Lobos, I97I, p. 98. 
bos vai considerar influências estruturais que dariam uma contribuição para essa consciência musical: a indígena e a católica. Dos povos ameríndios estariam presentes os curtos desenhos ritmo-melódicos, cantados em uníssono para sublinhar os movimentos da dança ou acompanhar as cerimônias religiosas. Da tradição católica, ele destaca o canto coletivo e polifônico.

Mas se haveria um rico material musical que revelava uma tradição sonora a indicar a existência de um Brasil musical, não haveria, contudo, um trabalho estético que fizesse frente a essa tradição, tal como já havia brotado, por exemplo, na literatura. Antes de tudo, é preciso atentar que Villa-Lobos não deplora a falta de uma tradição musical brasileira; o que ele afirma, antes, é que não havia uma consciência musical que expressasse a riqueza sonora do país, tal como em outras artes. Ainda faltava uma nacionalidade artística musical. Também é preciso considerar que, à época em que expôs essas breves reflexões sobre a importância da música folclórica para a cultura brasileira, Villa-Lobos já havia percorrido um caminho próprio com bastante intensidade e riqueza artística. O que consiste em dizer que o destaque para essa dupla ascendência histórica da música brasileira, ou seja, na canção ritualística dos indígenas e da polifonia católica, atende, de maneira muito esquemática, às necessidades expositivas dos elementos pedagógicos e didáticos do compositor. Em suma, Villa-Lobos está longe de reduzir toda a riqueza sonora pulsante no Brasil a esses dois elementos, e sua obra mesma, em seu conjunto, constitui-se muito além dessa dupla vertente.

Ora, é preciso demarcar o acento que dá o compositor ao processo histórico que legou os elementos que poderiam constituir uma linguagem musical brasileira, indo até os primórdios de nossa formação, da utilização mesma desses elementos. Nesse sentido, é possível destacar tanto a presença da música negra na obra de Villa-Lobos, quanto uma preocupação ecológica de expressar a presença incontornável da fauna e da flora brasileira, isto é, a potência natural como elemento constitutivo da realização musical. $\mathrm{O}$ mesmo valeria para as diferentes tradiçôes regionais. Na vastíssima obra do compositor, mesmo antes da semana de 22 e, portanto, do projeto do Canto Orfeônico, já havia um amplo tratamento de toda uma temática ligada àquilo que poderíamos associar a uma ideia reguladora de música do Brasil. Dão testemunho dessa visão de Villa-Lobos as Danças características africanas, A prole do bebê (I e II), Suite popular brasileira, Suite floral, Cançôes típicas brasileiras, e os poemas sinfônicos Uirapuru e Amazonas, ou ainda obras posteriores como a sinfonia 6, chamada Sobre as linhas das montanhas, e a Io, denominada Ameríndia. A lista seria vastíssima, na verdade.

As exposições teóricas registradas nos textos que dão conta das atividades em torno do Canto Orfeônico têm o mérito de nos oferecer a própria visão de Villa-Lobos sobre uma vertente importante de sua obra. Nesses textos, o que ele 
destaca acima de tudo é, em primeiro lugar, sua própria visão pedagógica musical e, a seguir, a importância do legado folclórico para a educação popular e infantil. Ora, no contexto dessa atuação pedagógica, em que a questão da identidade nacional brasileira era muito forte, se impôs a Villa-Lobos a tarefa de captar por meio da música os elementos multifacetados que se expressam nos diferentes cantos do Brasil, tanto do ponto de vista cultural e humanístico, quanto natural, para assim devolver ao povo aquilo de que ele mesmo foi autor ou com o que pudesse se identificar. E o mais importante é que essa visão estético-musical a serviço de uma concepção educativa já estava bem delineada no conjunto da obra villa-lobiana e dela vai continuar sendo sempre parte constitutiva essencial.

\section{Tentativa de conciliação das visões de Nietzsche e de Villa-Lobos}

Ao tentar mostrar as possíveis semelhanças entre Nietzsche e Villa-Lobos, levando em consideração a visão que os dois expuseram em suas obras sobre música e a temática popular e folclórica, assim como a importância dessas concepções no interior do projeto estético e cultural de cada um deles. No caso do filósofo, tratase de uma concepção mítica ligada à música dionisíaca como elemento capaz de suplantar séculos de uma tradição valorativa, o que implica, pela superação da música moderna, fazer brotar uma nova sonoridade cuja força não estava restrita ao campo das artes, mas dos valores amplos. No caso do compositor, a necessidade de ampliação da linguagem musical experimentada no âmbito própria das artes foi motivo para a utilização do material folclórico como força fundamental não apenas para a renovação da estrutura harmônica como também poderia significar o encontro de uma cultura consigo própria.

Dois são os pontos de partida de Nietzsche que o conduziram à sua meta em O Nascimento da Tragédia: sua interpretação da cultura trágico-dionisíaca grega e seu contato com a música do compositor Richard Wagner. Em suas primeiras obras, Nietzsche considerou a época mais vital e de maior potência entre os gregos aquela que ele denominou de cultura trágica. Da perspectiva filosófica, foi o período dominado pelos pensadores chamados de pré-socráticos; do ponto de vista mais amplo da cultura, é todo o período arcaico que culmina com a tragédia, tendo como pontos mais elevados a cultura épica de Homero, a poesia dos poetas líricos e o advento da tragédia. Nessa esfera, há um destaque dado por Nietzsche à música como elemento máximo de toda a cultura, e na relação entre obra de arte musical e mítica estaria todo o processo artístico, histórico e metafísico que teria culminado na tragédia grega. 
É na obra de Wagner que Nietzsche encontra a força artística capaz de fechar esse ciclo "dialético", cujo início fora dado com O Nascimento da Tragédia grega, passando por sua dissolução graças ao efeito devastador da filosofia socrática, a qual, por sua vez, chegaria ao seu fim com o soar dessa obra de arte musical alemã. De fato, se o otimismo científico socrático foi o responsável por dar cabo daquela cultura trágica baseada na união do apolíneo e do dionisíaco, pondo fim num tipo supremo de relação entre música e palavra, esse mesmo otimismo seria superado na medida em que música a palavra, outra vez postas na mesma relação que outrora fora característica da tragédia grega, destruiria os alicerces dos princípios socráticos.

É preciso atentar para o poder que Nietzsche atribui à música. Sendo por excelência a obra de arte dionisíaca, ao dar cabo da cultura trágica, Sócrates teria se voltado contra um tipo de cultura cujo elemento central era a música. Daí por que Wagner reveste-se de tamanha importância, porque só a obra de arte musical seria capaz de fazer reviver aquela potência sonora. Por isso, Nietzsche atribui tanta importância à música, porque se $O$ Nascimento da Tragédia expõe toda uma amplitude valorativa a ser superada, a música representa o núcleo mais importante desse projeto. Uma vez se livrando dos grilhões que há séculos determinam os valores ocidentais, à música estaria aberto o caminho para uma renovação valorativa mais ampla.

Nietzsche lembra que a tradição mais antiga da música grega ditirâmbica dionisíaca era tanto excitante quanto calmante. Além disso, sua singularidade estava também numa outra dimensão harmônica. "Os gregos possuíam uma sensibilidade finíssima, como é forçoso inferir da rigorosa caracterização das tonalidades, embora neles fosse muito menor a necessidade de uma harmonia acabada, realmente sonante". ${ }^{25}$ A esse fundo sonoro singular, que se distancia da sonoridade da música moderna, Nietzsche associa a concepção kantiana do sublime para analisar a tragédia grega, formulando aquilo que seria sua contribuição ao significado da obra de arte trágica para a cultura grega. ${ }^{26}$ Se os efeitos da tragédia representam a máxima afirmação da vida, essa visão está erguida sobre um pano de fundo sombrio, sobre o que há de terrível e problemático na existência. Assim como Dioniso representa o ciclo de nascimento e morte e sua música excita e acalma, a tragédia grega traz em si os aspectos terríveis de todo ser vivo ao mesmo tempo em que oferece um afirmativo dizer à vida. Não se trata, para o filósofo, de uma interpretação reduzida à moral da tragédia, como ocorre na tradição, mas de uma questão estética.

25 A Visão dionisíaca do Mundo $\$$ I, KSA I.557.

26 Nuno Nabais apresenta uma boa análise do lugar do sublime kantiano na filosofia do jovem Nietzsche, bem como sua importância para o debate em torno de Habermas e o pós-modernos (Nabais, 1997, pp. I8-35). 
Para aclarar o mito trágico a primeira exigência é buscar cabalmente o prazer peculiar dele na esfera estética pura, sem invadir o terreno da compaixão, do medo, do moralmente sublime. Como o feio e o desarmônico, que são o conteúdo do mito trágico, podem suscitar o prazer estético? [...] O mito trágico há de nos convencer de que inclusive o feio e o desarmônico são um jogo artístico. [...] esse fenômeno primordial da arte dionisíaca, difícil de apreender, só se torna compreensível por um caminho direto, e é apreendido imediatamente no milagroso significado da dissonância musical [musikalischen Dissonanz]. [...] O prazer que o mito trágico produz tem idêntica pátria que a sensação prazenteira da dissonância na música. $\mathrm{O}$ dionisíaco, com seu prazer primordial percebido inclusive na dor, é a matriz comum da música e do mito trágico. ${ }^{27}$

O caráter grandioso e que torna a cultura grega um exemplo é sua arte trágica. Mas a singularidade que Nietzsche atribui a sua própria compreensão dessa visão de mundo está em atribuir à música a fonte que permitiu aos gregos erigir tão singular cultura. Por isso o filósofo vai ser um entusiasta da música de Wagner, na medida em que defende que a renovação wagneriana frente à tradição da música tonal poderia abrir de novo o caminho para aquelas características da época trágica dos gregos. $\mathrm{Na}$ filosofia inicial de Nietzsche, juntamente com o esgotamento da tradição ocidental iniciada por Sócrates, estava também o ocaso da própria estrutura harmônica moderna. Daí a superação das duas serem parte de um mesmo projeto filosófico-artístico. Essas considerações de Nietzsche sobre a dissonância ${ }^{28}$ da música grega, seus efeitos apelativos ao feio e ao grotesco, ao mesmo tempo em que provoca uma apreciação estética verdadeira, será motivo para ele depois negar que a música wagneriana seja filiada à tradição grega, pois pertence ainda ao romantismo e ao que é mais alemão, mas também motiva Nietsche a continuar postulando a necessidade de uma música que não fosse mais romântica e alemã, mas dionisíaca e dissonante.

Se considerarmos que as composições de Wagner, especialmente Tristão e Isolda, constituem um contraponto importante ao sistema tonal, na medida em que começa a subverter seu cânon, é preciso reconhecer que o compositor leva a cabo suas inovações harmônicas ainda no campo das escalas tonais, mesmo que apontem para sua superação. Nesse sentido, podemos entender também o diálogo da obra de Villa-Lobos com Nietzsche, uma vez que o compositor brasileiro já se insere naquele movimento artístico que, em termos musicais, apelou para outras tonalidades e escalas para além do sistema tonal. E, mais ainda, empregou como

27 O Nascimento da Tragédia $\$ 24$, KSA I.I52.

28 Pierre Lasserre faz uma breve, mas importante exposição da dissonância em Nietzsche, mostrando o distanciamento do filósofo em relação à estética do belo defendida pelos clássicos (1905, pp. I03-109). 
critério para utilização dessas escalas sua natureza folclórica, lembrando a forma como Nietzsche havia interpretado a relação entre música e mito na cultura dionisíaca grega. Esse é um aspecto importante para compreender a obra de Villa-Lobos porque se suas composições desde cedo tiveram essa dupla característica, a de utilizar tanto as linguagens musicais de vanguarda quanto a folclórica, ele também foi bastante crítico das composiçôes modernas que se pautavam numa estética meramente experimental, produzindo uma arte que ele chamava de "música de papel”, um modernismo de mau gosto e feios sons. ${ }^{29}$

Essa é uma tomada de posição importante, porque define de maneira muito intensa o lugar de nosso compositor nas grandes linhas que demarcaram os debates e posicionamentos estéticos ao longo do século xx. Porque, como compositor, não resta dúvida que Villa-Lobos jamais poderia ser considerado um epígono, ou um romântico tardio. Sua obra é atravessada pelas experiências harmônicas e composicionais da modernidade, e a utilização do material folclórico, como vimos, é afim a essa estética. Por outro lado, um componente importante de sua obra é a associação do material temático de viés brasileiro com uma estrutura legada pela tradição, como é o caso de sua obra Bachianas Brasileiras. Com efeito, naquela que talvez seja a obra com a qual mais comumente se identifica o compositor, ele lança mão de um dos recursos mais característicos de Bach, a fuga, sempre em harmonia com peças inspiradas no cancioneiro brasileiro.

A dimensão do diálogo de Villa-Lobos com Bach pode ser avaliada pela forma como ele se estabelece. Não seria despropositado lembrar dos alertas que Adorno fez aos admiradores de Bach, defendendo que era preciso livrar o compositor de seus entusiastas. O filósofo contrapõe-se àqueles que quiseram fazer de Bach um consumador da música medieval, tornando-o motivo de celebração anual em festivais de órgãos; criticou, também, aquela tendência que ganhou corpo ao longo do século xx de querer interpretar o compositor a partir do contexto de sua época, especialmente pela utilização restrita de instrumentos antigos. Esquece-se, com isso, segundo Adorno, do paradoxo intrínseco à obra bachiana relativo à consciência polifônica, ou de como pode a música manifestar-se com pleno sentido em sua progressão harmônica de acordo com o baixo contínuo e manter a simultaneidade de vozes independentes. ${ }^{30}$ Já com respeito à execução de Bach utilizando apenas instrumentos de época, Adorno lembra, entre outras questôes, das obras do compositor sem indicações de instrumentos, e de como ele mesmo se mostrava constantemente insatisfeito com o que havia disponível. E, argumenta Adorno, se Bach preferiu o som do cravo ao do piano, é porque este ainda era muito rudimentar na época

29 Cf. Villa Lobos, I97I, pp. 99-I00.

30 Adorno, 1963, p. 136. 
do compositor. Por isso, Adorno considera que as poucas instrumentações feitas por Schöenberg e Webern para as obras de Bach seriam modelos de atitude de consciência perante Bach e corresponderiam à sua verdade. ${ }^{3 \mathrm{I}}$

Nenhum desses três posicionamentos diante da obra de Bach será aquele adotado por Villa-Lobos. E se Adorno se opõe aos dois dogmatismos frente à obra do compositor alemão, é para defender também uma certa leitura dogmática, numa recriação transpositiva, que, no fim das contas, recai naquilo que ele mesmo critica, ou seja, um certo tratamento musical que representaria a verdadeira consciência bachiana. Se Villa-Lobos se volta para a estética da composição de Bach é para recriá-la numa atmosfera nova, em outra dimensão, tanto espacial quanto temporal, a do Brasil do século xx, em harmonia com a expressão do canto folclórico e popular.

A maior substância técnica e psicológica da inspiração de sua [de Bach] monumental obra está baseada no canto livre da terra, através das expressōes espontâneas dos homens simples e inconvencionais. [...] Devemos compreender, amar e cultivar a música que vem e vive, direta ou indiretamente, de nossa terra e universalizá-la com fé e consciência. ${ }^{32}$

Visão a que poderíamos chamar de heterodoxa em relação a Bach, a de Villa-Lobos procura encontrar essa sonoridade que parte de um outro lugar, e, tendo ganhando uma linguagem universal, permite estabelecer um diálogo que se entranha noutro território e aí o encontro de dois sons e de duas gentes que falam a mesma língua.

Muito já se escreveu sobre a "atuação" de Villa-Lobos e a filiação de sua música e, por consequência, de sua visão do folclore, ao período Vargas do Estado Novo. Escapa ao objetivo deste texto analisar essas críticas; a despeito disso, parece importante para o contexto de nossa discussão considerar a interpretação de Wisnic, segundo quem há uma inspiração platônica no ideal de Villa-Lobos de uma pedagogia tal como posta em prática no Canto Orfeônico. Não porque o compositor fosse um leitor direto do filósofo grego, mas porque recebeu essa influência marcante da cultura ocidental de um equacionamento do poder psíquico-políticosocial em face de sua utilização pelo Estado. ${ }^{33}$ Adepto da crítica à cultura de massa urbana, cuja decadência estava evidente pela larga utilização do gramofone como aparelho de repetição, Villa-Lobos teria visto no projeto pedagógico do Canto Orfeônico aquela união platônica entre música e Estado (aqui o Estado Novo de Getúlio Vargas) com a finalidade de educar a massa urbana.

3I Cf. Adorno, I963, p. I46.

32 Villa-Lobos, I97I, p. I24.

33 Cf. Wisnic, 1982, p. I39. 
Se é legítima essa interpretação que Wisnic faz da atuação de Villa-Lobos como compositor-pedagogo, associando sua vinculação à política varguista ao ideal platônico de uma música a serviço do Estado, talvez esse caminho possa indicar uma fissura no projeto mesmo de Villa-Lobos de submeter aquela sua parte da estética musical baseada no folclore às ideias políticas do "tempo de agora" (para lembrar a expressão de Nietzsche). Como Wisnic mesmo expõe, a utilização da música como elemento de educação política, em Platão, requer antes uma reflexão sobre os diferentes modos musicais praticados na Grécia, tomando partido pelos modos apolíneos dóricos e condenando a música dionisíaca lídia. Ora, o modo dórico contém um ethos capaz de educar que o lídio, possuidor apenas de um pathos, não possui. Nesse sentido, o modo dórico, sistema pentatônico sem meio tom, contrasta com o lídio, um sistema heptatônico com um semiton. Enquanto a música dória se presta à religião do estado, a lídia pertence ao universo religioso dionisíaco. ${ }^{34}$ Portanto, o que está em harmonia em Platão, produz uma completa dissonância em Villa-Lobos, se se considera que ele estava investido de uma ética platônica.

Ora, vimos que Nietzsche enxergou na atuação da filosofia socrática a instauração de uma cisão de mundo inconciliável no mundo grego entre a visão dionisíaca e a visão socrática, de que Platão é herdeiro. Nietzsche defendeu uma relação intrínseca entre a música dionisíaca e o mito, na medida em que aquela era, no fundo, responsável por gerar este. O mundo apolíneo homérico do mito é uma descarga em imagens de um fundo afigural sonoro dionisíaco. É, pois, contra o esse mundo mítico-musical, tanto homérico quanto dionisíaco, que Platão vai se voltar na República, justamente porque uma cultura assim constituída não se rende ao trabalho filosófico da racionalidade. Aqueles aspectos destacados por Nietzsche, isto é, bárbaros, selvagens, grotescos, dissonantes, que faziam o grego gostar do feio, e se alegrava com o destino cruel dos heróis, foram arrancados do mundo grego com a vitória do socratismo.

Como criação coletiva popular ligada aos rituais de canto, dança, trabalho etc., a canção folclórica partilha desses mesmos dois elementos que Nietzsche destacava obra de arte dionisíaca, isto é, o mito e a música, e que teria culminado naquela forma em que confluíam todos os formatos artísticos, a tragédia, um evento que estava a serviço da vida, e não da moral. E no livro III da República, o Sócrates de Platão, em seu modelo de educação para a justiça, condena tanto a poesia homérica ${ }^{35}$ quanto a música jônia e lídia, cujas harmonias conduzem à languidez, à ociosidade, e são propícias aos banquetes e à embriaguez. ${ }^{36} \mathrm{Um}$ últi-

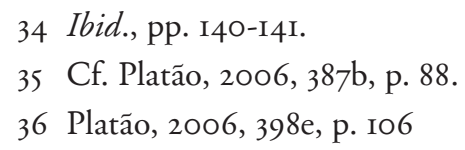


mo aspecto que corrobora essa interpretação é o fato de que Platão, como lembra Wisnic, defende que para a boa educação musical a música deve estar subordinada à palavra. ${ }^{37}$ Esse é um ponto central da estética de Nietzsche, pois, como vimos antes, uma das denúncias mais fortes que ele faz à ópera é a tendência de nela a palavra ser senhora e a música escrava. É certo que Villa-Lobos não partilharia da visão platônica no que tange à relação entre música e palavra, sendo este um de seus aspectos do socratismo teórico. A esse respeito, Mario de Andrade nos oferece um bom exemplo de como funciona a interação entre música e palavra, e também de como Villa-Lobos modelava suas obras. Assim, comentando a apresentação do poema sinfônico Amazonas, destaca as mudanças por que passou a obra, pois antes o que era inspirado em textos gregos passou a ser cantado noutro texto de inspiração ameríndia. Segundo Mario de Andrade, a obra, antes medíocre, ganhou vida nova, tornando-se grandiosa.

E me agrada especialmente esta sem-cerimônia com que Villa-Lobos atribui à mesma música possibilidade de expressar a Grécia e os selvagens de Marajó - da mesma forma com que Haendel de árias de amor fez depois árias sacras do Messias. Isso é que salva Villa-Lobos, tão preso ainda à estética pesada e falsa da música programática, de se desperdiçar inteiramente nela. Aliás, força é notar que a remodelação que Villa-Lobos fez no seu antigo poema sinfônico, foi, creio, tão enorme a ponto de lhe criar pelo menos em parte uma temática nova. Seria interessante estudar comparativamente este Amazonas de agora e o poema antigo. ${ }^{38}$

Essa forma com que trabalha o material temático, a relação entre música e palavra corrobora, pois, aquela visão nietzschiana de que a música tolera junto a si a palavra, mas dela não depende. Numa obra musical, é a palavra que está subordinada à música. Por isso, talvez seja possível afirmar, nas pegadas da filiação filosófica a Platão de que trata Wisnic, que Villa-Lobos lançou mão de uma visão dionisíaca de mundo para pôr em ação um projeto que seria da visão socrática de mundo, pois tanto sua concepção sobre a união entre os modos folclóricos e a linguagem musical, assim como a relação entre sons e palavras mais se harmonizam com as considerações de Nietzsche sobre o dionisíaco, do que com o socrático-platônico. ${ }^{39} \mathrm{O}$ próprio Nietzsche tratou de fazer a crítica de sua

37 Wisnic, 1982, p. I40.

38 Mario de Andrade, 2013, p. 379.

39 Nesse aspecto, o próprio Wisnic (p. 174) encontra um tom desarmônico na trajetória de Villa-Lobos, pois da perspectiva do registro estético da obra musical teríamos uma concepção mitopoética, enquanto da perspectiva do registro do programa orfeônico teríamos uma concepção pedagógico-autoritária. Ora, esse duplo registro só faz sentido quando se lê a atuação do compositor à luz da filosofia platônica e do lugar que nela ocupa 
filosofia inicial ao denunciar essa espécie de contradição lógica em seu livro, uma vez que subordinou sua visão dionisíaca ao contexto político de sua época, e seu rompimento com Wagner está muito ligado à separação entre a esfera estética e a moral e política.

Esse diálogo quasi una fantasia entre Nietzsche e Villa-Lobos torna possível uma dupla apreciação de benefício mútuo. Em primeiro lugar, porque nos permite vislumbrar uma obra de arte dionisíaca, em sua relação entre música e palavra, numa ligação com a cultura, brotando para além do contexto em que foi exposto, tal como ocorre com $O$ Nascimento da Tragédia, abrindo a possibilidade de ver, também, a obra de Villa-Lobos pela ótica nietzschiana; mas também, em seguida, torna possível compreender a música de Villa-Lobos por sua potência artística para além de uma visão moralizante. Se, como afirma Jankélévicht sobre Bartók e Villa-Lobos, eles não se prendem a nenhum preconceito, tampouco a nenhuma conveniência tradicional, sendo ambos práticos do murro e da percussão furiosa, poderíamos concluir que a música do compositor brasileiro, para lembrar a fórmula de Nietzsche, nos conduz para uma visão de mundo em que a moral é vista sob a ótica da arte, mas a arte, sob a ótica da vida.

O poeta Drummond, descrevendo uma apresentação do Canto Orfeônico sob a batuta de Villa-Lobos, fala dos efeitos de uma comunhão cósmica que sentiam os presentes, ao mesmo tempo em que mantinham sua individualidade, $o$ que, sem dúvida, nos faz lembrar daquele jogo artístico vital entre o dionisíaco e o apolíneo exposto por Nietzsche em $O$ Nascimento da Tragédia.

Assim é que eu vejo Villa-Lobos [...]. Quem o viu um dia comandando o coro de quarenta mil vozes adolescentes no estádio do Vasco da Gama, não pode esquecê-lo nunca. Era a fúria organizando-se em ritmo, tornando-se melodia e criando a comunhão mais generosa, ardente e purificadora que seria possível conceber. A multidão em torno vivia uma emoção brasileira e cósmica, estávamos tão unidos uns aos outros, tão participantes e ao mesmo tempo tão individualizados e ricos de nós mesmos, na plenitude de nossa capacidade sensorial, era tão belo e esmagador, que para muitos não havia jeito senão chorar; de pura alegria. ${ }^{40}$

o programa musical da república. E o artista Villa-Lobos estava longe de compartilhar do dogmatismo do filósofo grego com relação à música. Lá onde Platão pensava em banir certos modos e escalas, é justamente onde o compositor foi buscar muita de sua estética musical. Platão restringe; Villa-Lobos amplia.

40 Drummond, i971, p. 67. 


\section{Referências}

Abbate, C. \& Parker, R. A history of Opera. Londres: Penguin, 2012.

Adorno, T. W. "Bach gegen seine Liebhaber verteidigt". In: Prismen. Kulturkritik und Gesellschaft. Munique: Deutscher Taschenbuch Verlag, 1963, pp. I33-I46.

Almeida, R. A inteligência do folclore. Rio de Janeiro: Companhia Editora Americana, I974.

Andrade, M. Música, doce música. Rio de Janeiro: Nova Fronteira, 2013.

Bernstein, G. Sobre poética e forma em Villa-Lobos. Primitivismo e estrutura nos Choros Orquestrais. Curitiba: Editora Prismas, 2014.

Drummond de Andrade, C. "Glória amanhecendo". In: Presença de Villa-Lobos. MEC. Volume 6, 1971, pp. 67-69.

Jankélévicht, V. "Béla Bartók". In: Primeiras e últimas páginas. São Paulo: Papirus, I994, pp. 3II-323.

Kiefer, B. Villa-Lobos e o modernismo na música brasileira. Porto Alegre: Editora Movimento, 1986.

Lasserre, P. Les idées de Nietzsche sur la musique. Paris: Societé du Mercure de France, 1905 .

Lima, M. J. S. "Canção popular e música dionisíaca em Nietzsche". In: Cadernos Nietzsche (vol. 38, n. I). Guarulhos/Porto Seguro, 2017, pp. 58-83.

Nabais, N. A metafisica do trágico. Lisboa: Relógio D’Água Editores, 1997.

Nietzsche, F. Sämtliche Werke. Kritische Studienausgabe (Ksa: I5 vols.). Hrsg. von G. Colli und M. Montinari. Berlin/New York: de Gruyter, 1988.

Oliveira, W. C. Com Villa-Lobos. São Paulo: Edusp, 2009.

Platão. A república. Trad. Anna Lia Amaral de Almeida Prado. São Paulo, Martins Fontes, 2006.

Salles, P. T. Villa-Lobos: processos composicionais. Campinas: Editora da Unicamp, 2 OII.

Teixeira, A. "Villa-Lobos". In: Presença de Villa-Lobos. mec. Volume I, I965, pp. I3-I4.

Villa-Lobos, H. "Educação cívico-artística". In: Presença de Villa-Lobos. mec. Volume 5, 1970, pp. IOI-IO4.

Villa-Lobos, H. "Educação musical". In: Presença de Villa-Lobos. mec. Volume 6, I97I, pp. 95-I30.

Wisnic, J. M. "Getúlio da Paixão Cearense (Villa-Lobos e o Estado Novo). In: SQuefF, Ênio \& Wisnic, J. M. O nacional e o popular na cultura brasileira. São Paulo: Brasiliense, I982, pp. I28-190. 